\title{
THE BEGONIA OF VERACRUZ: ADDITIONS AND REVISIONS
}

\author{
Patrick D. McMillan ${ }^{1}$, Graham WyatT ${ }^{1}$ and Rekha Morris ${ }^{2}$ \\ ${ }^{1}$ Clemson University, Dept. of Biological Sciences, 132 Long Hall, \\ Box 340314, Clemson, South Carolina, U.S.A. 29634-0314 \\ ${ }^{2}$ Woodland Circle, Pendleton, South Carolina, U.S.A.
}

\begin{abstract}
Field explorations and examination of herbarium specimens were utilized to document the diversity of Begonia species found within the state of Veracruz. Thirty species were found to be of native occurrence in the state. One species, Begonia involucrata is reported as new to Mexico and is disjunct from the nearest documented populations in Costa Rica. Begonia sericoneura is added as new to the state of Veracruz. Examinations of new material, live specimens and re-examination of previously collected material were utilized to revise descriptions of Begonia carolineifolia, B. involucrata, B. lyniceorum, $B$. sericoneura and B. sousae. Stomatal arrangements were determined for 28 of the 30 taxa. Solitary stomatal arrangements in section Gireoudia are shown to be more common than previous reports would indicate with 7 of the 18 species examined not exhibiting stomatal clusters. A key to the native taxa of the state of Veracruz is presented. Habitat, elevational and distributional patterns are also reported and discussed.
\end{abstract}

Key words: Begonia, Mexico, State of Veracruz, taxonomy.

\section{RESUMEN}

Para documentar la diversidad de las especies de Begonia en el estado de Veracruz se realizaron exploraciones de campo y se revisaron especímenes de herbario. Se encontraron 30 especies nativas en el estado. Begonia involucrata se cita como nueva para México con la población disyunta más cercana en Costa Rica. Begonia sericoneura es nueva para el estado de Veracruz. La revisión de material adicional, especímenes vivos y de ejemplares previamente colectados se usó para revisar las descripciones de Begonia carolineifolia, $B$. involucrata, B. lyniceorum, B. sericoneura y B. sousae. Se determinó la disposición de los estomas de 28 de los 30 taxa encontrados. La ocurrencia de estomas solitarios en la sección Gireoudia es más común que lo indicado por registros previos, pues 7 de las 18 especies examinadas carecen de agregados estomatales. Se presenta una clave para los taxa nativos 
del estado de Veracruz. Se proporciona y discute también la información relativa al hábitat, así como a los patrones de altitud y de distribución.

Key words: Begonia, estado de Veracruz, México, taxonomía.

\section{INTRODUCTION}

Jiménez \& Schubert (1997) revised the native species of Begonia in the state of Veracruz. Their important treatment lists 28 taxa for the state and provides a key and description for each of these species. Our research in the state of Veracruz was intended to extend the work of Jiménez \& Schubert (1997) by documenting the diversity of Begonia in the state and recording observations on the habitat and morphology of the lesser known species. This research has lead to the discovery of two additional taxa for the state, one of which is new to Mexico, and has increased the documented range for many of the species beyond the previously reported geographical and elevational limits. Additionally, the key presented in the Jiménez \& Schubert (1997) treatment is not a fully-working dichotomous key and is not dichotomous at couplets 12-13, 14-16 and 21-24. This results in a lack of adequate identification of 16 out of the 30 species naturally found within Veracruz. No other comprehensive keys to the species of Veracruz are available, with the exception of keys including all of the world's Begonia species, which makes identification rather tedious for the non-expert (Smith et al., 1986; Golding and Wasshausen, 2002). We have included a key to the native species found within Veracruz based upon morphological observations taken from herbarium specimens, field observations of live specimens, and the prior treatments of other researchers. When preparing the key we sought, where possible, to make use of vegetative characters that are present for most species throughout the year rather than on transient characters of the inflorescence. We have included additional pertinent information on the ecology, distribution, and morphology for several of the taxa including new insights on their anatomy and refinements of previous descriptions.

\section{METHODS}

Previous literature was reviewed and prior collections were consulted from the following herbaria (CLEMS, DUKE, F, GH, MEXU, NY, XAL). Attempts 
were made to borrow or examine collections from NOLS, but the curatorial staff denied us access to the specimens and refused further correspondence. Using records gathered from previous research Morris began exploring regions that appeared to be rich in Begonia species and identified other under-explored areas, such as Zongolica that appeared to exhibit the appropriate geography and geology to support a diversity of Begonia species. Seven geographical areas were identified and visited by Morris (Fig. 1). McMillan accompanied Morris to Veracruz during March of 2004. The survey technique involved the attempted relocation of existing populations and exploration of the remaining fragments of existing forests in these areas. It became apparent that several descriptions needed revision. The descriptions presented below were based on herbarium specimens as well as living material, which was subsequently collected, dried and deposited at CLEMS or XAL. Stomatal arrangements were determined for 27 of 30 species. The stomatal arrangement was determined by examination of epidermal peels taken from the lower leaf surfaces of fully-expanded, adult leaves of at least three individuals from one or more populations, or when living material was not at hand, using the same method from dried herbarium specimens (Hoover, 1986). Preserved slides are deposited with their representative herbarium vouchers at CLEMS.

\section{RESULTS}

Thirty species were identified as naturally occurring in the state of Veracruz. One species, Begonia involucrata Liebm. has not previously been identified for Mexico and another, B. sericoneura Liebm. has not been previously reported from the state of Veracruz. Plants of Begonia involucrata found growing in the lowland, wet, evergreen tropical forests of volcanic regions near Lago Catemaco were found to differ vegetatively from published descriptions and from herbarium specimens examined from Costa Rica and Panama. These highly disjunct plants are here considered to be a form of $B$. involucrata but future research may find that they deserve some level of taxonomic recognition. Of the 30 species located, two are endemic to Veracruz (B. lyniceorum BurtUtley and $B$. multistaminea Burt-Utley); including the previously mentioned Veracruz endemics, ten taxa are endemic to Mexico (B. bakeri Know. \& West, B. carolineifolia Regel, B. falciloba Liebm., B. hydrocotylifolia Otto ex Hook., B. imperialis Lem., B. karwinskyana A. DC., B. pudica Smith \& Schubert, and B. sousae Burt-Utley). 


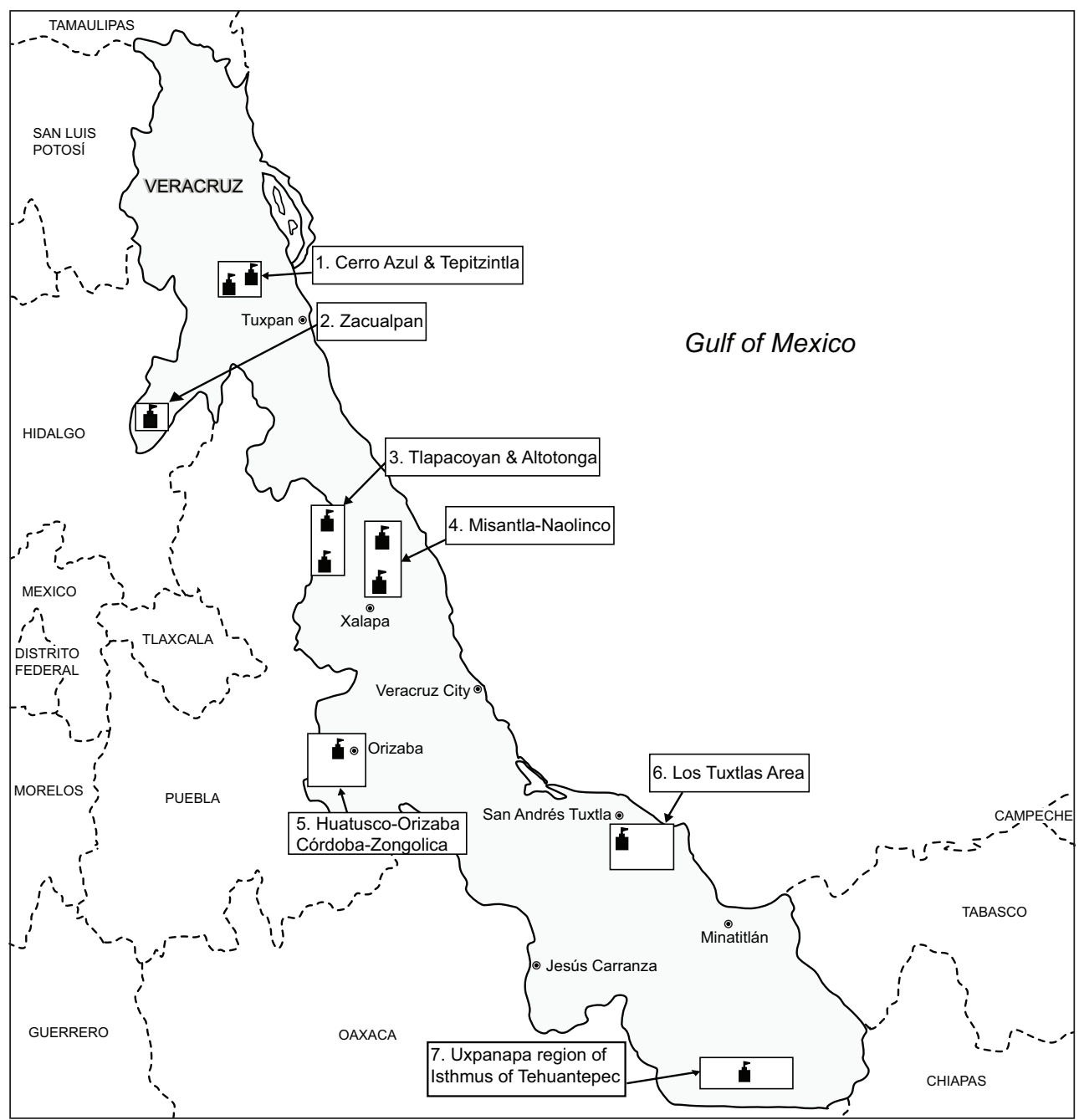

Fig 1. Major areas of Begonia habitat in Veracruz State visited.

Stomatal arrangements were examined for most species and are reported below in Table 1. This represents the first published report of stomatal arrangements for several recently described or rarely collected species including B. lyniceorum, B. karwinskyana, B. multistaminea, and B. sousae. Of particular interest is the verification of solitary stomatal arrangements in $B$. carolineifolia, B. fusca, B. hydrocotylifolia, B. involucrata, B. peltata, and B. thiemei. This 
Table 1. Stomatal arrangements in native taxa of Begonia in Veracruz.

\begin{tabular}{|c|c|}
\hline Species & Stomatal arrangement \\
\hline Begonia barkeri Know. \& West (sect. Gireoudia) & Clusters $(1-3+)$ \\
\hline Begonia carolineifolia Regel (sect. Gireoudia) & Solitary \\
\hline Begonia falciloba Liebm. (sect. Knesebeckia) & Solitary \\
\hline Begonia fischeri Schrank (sect. Begonia) & Not examined \\
\hline Begonia fusca Liebm. (sect. Gireoudia) & Solitary \\
\hline Begonia glabra Aubl. (sect. Wageneria) & $\begin{array}{l}\text { Solitary or weakly grouped } \\
\text { in pairs }\end{array}$ \\
\hline Begonia gracilis Kunth (sect. Quadriperigonia) & Solitary \\
\hline Begonia heracleifolia Schltdl. \& Cham. (sect. Gireoudia) & Clusters $(1-3+)$ \\
\hline Begonia hydrocotylifolia Otto ex Hook. (sect. Gireoudia) & Solitary \\
\hline Begonia imperialis Lem. (sect. Weilbachia) & Solitary \\
\hline Begonia incarnata Link \& Otto (sect. Knesebeckia) & Solitary \\
\hline Begonia involucrata Liebm. (sect. Gireoudia) & Solitary \\
\hline Begonia karwinskyana A. DC. (sect. Gireoudia) & Clusters $(1-4)$ \\
\hline Begonia ludicra A. DC. (sect. Weilbachia) & Solitary stomata \\
\hline Begonia lyniceorum Burt-Utley (sect. Weilbachia) & $\begin{array}{l}\text { Clusters }(1-2, \text { rarely } 3) \text {, } \\
\text { more than } 1 / 2 \text { are solitary }\end{array}$ \\
\hline Begonia manicata Brongn. ex Cels.(sect. Gireoudia) & Clusters $(1-3+)$ \\
\hline Begonia multistaminea Burt-Utley (sect.Gireoudia) & Clusters (1-3) \\
\hline Begonia nelumbiifolia Schltdl. \& Cham. (sect. Gireoudia) & Clusters (1-many) \\
\hline Begonia oaxacana A. DC. (sect. Parietoplacentalia) & Solitary \\
\hline Begonia peltata Otto \& Dietr. (sect. Gireoudia) & Solitary, rarely paired \\
\hline Begonia pinetorum A. DC. (sect. Gireoudia) & Clusters (1-3) \\
\hline Begonia plebeja Liebm. (sect. Gireoudia) & Not examined \\
\hline Begonia polygonata Liebm. (sect. Gireoudia) & Clusters $(1-2)$ \\
\hline Begonia pudica L.B. Smith \& B.G. Schub. (sect. Gireoudia) & Clusters $(1-2+)$ \\
\hline Begonia pustulata Liebm. (sect. Weilbachia) & Solitary \\
\hline Begonia sartorii Liebm. (sect. Gireoudia) & Solitary or weakly clustered \\
\hline Begonia sericoneura Liebm. (sect. Gireoudia) & Clusters (1-3) \\
\hline Begonia sousae Burt-Utley (sect. Gireoudia) & Clusters (1-3) \\
\hline Begonia thiemei C. DC. (sect. Gireoudia) & Solitary \\
\hline Begonia wallichiana Lehm. (sect. Doratometra) & Solitary \\
\hline
\end{tabular}


represents the verification of five species in addition to the one previously verified species, B. hydrocotylifolia, from section Gireoudia, which show stomata that are not arranged in clusters (Doorenbos et al., 1998). Stomatal arrangement has been used as a character state for delineation of sections in Begonia but our results suggest that it may not be a reliable character (Doorenbos et al., 1998). Section Gireoudia has been considered to characteristically display clustered stomata, but our results indicate that only 13 out of 19 species sampled from this section display stomatal clusters and that the presence of clusters is not a general characteristic of section Gireoudia. Refinements or corrections to previously published morphological descriptions of several of the taxa identified in Veracruz are reported below.

Regional diversity

Table 2 reports the regional diversity of Begonia in the areas we visited in Veracruz. From our field studies, examination of herbarium records and literature it would appear that the highest diversity within the region is to be found in the central highlands in the environs surrounding Huatusco, Orizaba, Córdoba, and Zongolica. In this region we have confirmed the existence of 20 species. Within Veracruz, B. carolineifolia is apparently confined to this region, though it is locally abundant. A second area with a similar composition of species, but with less diversity is to be found in the montane environs near Naolinco and Misantla (10 species) including one Veracruz endemic (B. multistaminea). Two regions with less similar suites of species associated with low-elevation wet, broadleaf tropical forests include the southern (Uxpanapa) region of the Isthmus of Tehuantepec and the Sierra de Los Tuxtlas region. The Isthmus contains one endemic (B. lyniceorum) and one near endemic (B. imperialis), which is also found in adjacent areas of Chiapas. Begonia pustulata has been reported from the Isthmus but upon examination of material reported in Jiménez and Schubert (Nee 30001) it is apparent that the specimens upon which this report was made are actually representative of typical specimens of Begonia imperialis with 2 tepals on staminate flowers. The Los Tuxtlas region contains the majority of known populations for the rare and localized $B$. sousae as well as the only known location for $B$. involucrata in Mexico. It is important to note that the vast majority of species found in the state are found in areas without pronounced, extended dry periods and nearly every species is found in association with highcalcium (limestone) or mafic (volcanic) rock with high $\mathrm{pH}$. 
Table 2. Regions of collections/observations and elevational ranges for native species of Begonia in Veracruz. Regions correspond to those in fig. 1.

\begin{tabular}{|c|c|c|}
\hline Species & Area & $\begin{array}{l}\text { Elevational range } \\
\text { (in meters) }\end{array}$ \\
\hline Begonia barkeri Know. \& West & 4,5 & $150-1600$ \\
\hline Begonia carolineifolia Regel & 5 & to 1100 \\
\hline Begonia falciloba Liebm. & 5 & to 1350 \\
\hline Begonia fischeri Schrank & widely distributed & $0-1500$ \\
\hline Begonia fusca Liebm & $1,2,4,5$ & $1300-2500$ \\
\hline Begonia glabra Aubl. & $3,4,6,7$ & $100-1425$ \\
\hline Begonia gracilis Kunth & 5 & $1500-2200$ \\
\hline Begonia heracleifolia Schltdl. \& Cham. & $1,2,3,4,5,6,7$ & $130-1700$ \\
\hline Begonia hydrocotylifolia Otto ex Hook. & 5 & $600-1500$ \\
\hline Begonia imperialis Lem. & 7 & $100-150$ \\
\hline Begonia incarnata Link \& Otto & $1,2,3,4,5$ & $1050-1700$ \\
\hline Begonia involucrata Liebm. & 6 & 488 \\
\hline Begonia karwinskyana A. DC. & 1 & $800-1200$ \\
\hline Begonia ludicra A. DC. & $3,4,5$ & $900-1350$ \\
\hline Begonia lyniceorum Burt-Utley & 7 & $100-150$ \\
\hline Begonia manicata Brongn. ex Cels. & $2,3,4,5,7$ & $950-1600$ \\
\hline Begonia multistaminea Burt-Utley & 3,4 & $1300-1900$ \\
\hline Begonia nelumbiifolia Schltdl. \& Cham. & $1,3,4,5,6,7$ & $0-1000$ \\
\hline Begonia oaxacana A. DC. & 5 & to 1750 \\
\hline Begonia peltata Otto \& Dietr. & 5 & to 600 \\
\hline Begonia pinetorum A. DC. & 5,6 & to 750 \\
\hline Begonia plebeja Liebm. & 5 & $200-1680$ \\
\hline Begonia polygonata Liebm. & 5 & to 600 \\
\hline Begonia pudica L.B. Smith \& B.G. Schub. & 2,4 & $1500-2300$ \\
\hline Begonia pustulata Liebm. & 6 & $100-650$ \\
\hline Begonia sartorii Liebm. & 5 & to 924 \\
\hline Begonia sericoneura Liebm. & 5,6 & to 500 \\
\hline Begonia sousae Burt-Utley & 3,6 & to 650 \\
\hline Begonia thiemei C. DC. & 5,6 & $170-650$ \\
\hline Begonia wallichiana Lehm. & 2,3 & $10-720$ \\
\hline
\end{tabular}




\section{DISCUSSION AND DESCRIPTIONS OF SELECTED SPECIES}

\section{Begonia carolineifolia Regel}

This species is often confused with Begonia thiemei. The two species display compound foliage, but share few other characters. Burt-Utley (1985) points to sparser pubescence, larger sepals, and more numerous and larger stamens in B. thiemei as characters useful in separation of the species. In addition to these characters we have found that the leaves of $B$. carolineifolia are much thicker (coriaceous) than the membranaceous leaves of $B$. thiemei when living. The larger leaves with longer petioles of $B$. thiemei are so thin and fragile upon drying that they frequently disintegrate and fracture when dried for herbarium specimens. The lower leaf surface and petioles of $B$. carolineifolia are typically villous with rufous trichomes when young and tend to become glabrate in age rather than sparingly pubescent to glabrous as in $B$. thiemei. Stipules are likewise rufous villous towards the base in $B$. carolineifolia and glabrous in $B$. thiemei. In addition to these vegetative characters, $B$. carolineifolia produces pink to whitish flowers rather than the greenish flowers of $B$. thiemei. The three capsule wings are sub-equal in $B$ carolineifolia and highly unequal in $B$. thiemei with one longer wing, 14-17 mm long and two much smaller wings to $5 \mathrm{~mm}$ long. Flowering season only slightly overlaps, with $B$. carolineifolia flowering from November to April and B. thiemei beginning flower in March and extending into June.

In Veracruz, B. carolineifolia is apparently confined to the highland regions in the vicinity of Orizaba and Córdoba at middle elevations (to $1100 \mathrm{~m}$ ) growing in shallow soil around limestone and other sedimentary rock outcroppings or rarely as a low epiphyte in semi-evergreen montane forests or montane deciduous forests. It is locally common to abundant in available habitat in this region. Begonia thiemei is more frequent at lower elevations (typically below $650 \mathrm{~m}$ ) and is found primarily along streams and in protected areas (coves) within tall, broadleaf tropical forests (selva alta perennifolia). Specimens at the Field Museum (F), identified as $B$. carolineifolia from the Biological Station near Lake Catemaco, are representative of B. thiemei.

\section{Begonia involucrata Liebm.}

Newly reported collections: MEXICO. Veracruz: Mun. San Andrés Tuxtla, selva alta perennifolia (wet, broad-leaf evergreen tropical forest) adjacent to stream 
and cascades at Poza Reina, forming large colonies along moist to wet banks in deep, rich, organic soils over volcanic rock, in association with Begonia sousae Burt-Utley, Begonia glabra Aubl. and Begonia heracleifolia $x$ nelumbiifolia. $18^{\circ} 21^{\prime} 52.8^{\prime \prime}$ N. 9458'14.7" W. Elevation: 488 meters above mean sea level. 9 March 2004, Rekha Morris RM-04-120 (CLEMS), specimen identified by P. D. McMillan; same location, 18 March 2004, Patrick D. McMillan 7311 with Rekha \& Michael Morris (CLEMS, XAL); same location, 21 October 2004, Rekha Morris RM-04159, RM-04-160 (CLEMS).

Description: Weakly suffrutescent perennial with ascending stems, to $1 \mathrm{~m}$ or more in length, mostly unbranched, sometimes with one axillary branch; internodes elongate, either glabrous or with sparse setose trichomes. Leaves simple, thin, membranaceous, asymmetrical, slightly transverse or oblique, 10-14 palmately nerved, broadly ovate to suborbicular, mature leaves mostly $12-25 \mathrm{~cm}$ long and 17 $35 \mathrm{~cm}$ wide, wider than long. Leaf base strongly cordate often with overlapping bases. Leaf surfaces primarily glabrous above or with very widely scattered strigose trichomes on the major veins. Major veins with scattered strigose trichomes on the lower leaf surface, becoming rather densely pubescent with strigose hairs towards petiole attachment, intervein areas papillose below. Leaf margins dentate-ciliate or serrate ciliate. Leaf apex attenuate-acuminate, most or all mature leaves with an additional attenuate-acuminate extension (lobe) at vein 4 in addition to the cuspidateacuminate leaf apex at vein 5, thus giving the leaf a "two-tailed" appearance. Stomata in solitary arrangements, not in clusters. Petioles light green with scatttered strigose and setose pubescence consisting of whiplash trichomes on the lower portions of the petiole, upper portions becoming densely setose with shaggy and sometimes rufous-colored trichomes. Mature plants displaying petioles 10-30 (50) $\mathrm{cm}$ long. Stipules deciduous, lance-triangular, keeled with acute to moderately obtuse apex, moderately pilose. Inflorescence exceeding the leaves, cymose, symmetric, few to many-flowered, male flowers opening significantly earlier than the female flowers. Peduncles 15-20 (30) cm long, sparsely pubescent below with strigose to setose trichomes, becoming more densely pubescent above with numerous rufous-setose trichomes. Bracts caducous, the outer broadly ovate and encircling the inner bracts, outer surface with strigose trichomes, rufous in coloration, the inner surface glabrous. Staminate flowers with pedicels 5-20 mm long, tepals 2, a clear white, broadly ovate to obovate, fleshy, glabrous, $8-12 \mathrm{~mm}$ long and wide. Stamens $27-42$, filaments $1.0-$ $1.5 \mathrm{~mm}$ long, slightly longer than the anthers which range from $1.0-1.2 \mathrm{~mm}$ long, anthers broadly ovate to oblong. Pistillate flowers similar to staminate flowers with pedicels from 25-34 mm long at capsule maturity, tepals 2, also a clear white in color. 
Ovary trilocular with bilamellate placentation, glabrous. Styles 3, connate at base for approximately $1 / 2$ their length, stigmas bicornute, papillate. Capsules $8-11 \mathrm{~mm}$ long, 3-winged, the wings unequal with the largest 15-18 (20) $\mathrm{mm}$ long and 10-13 mm wide, obovate to elongate-dolabriform, the apex broadly obtuse or truncate, often lobed apicaly, the smaller wings asymmetric and lunate. Flowering from February to April, possibly sporadically at other times.

These collections represent the first reports of this species for Mexico. The population was located by Rekha and Michael Morris, who brought several leaves to McMillan for identification to species. The site was revisited to determine the identity of the species nine days later. This species is the type for section Gireoudia despite the fact that it displays a rather unusual morphology compared to most other species of the section (Doorenbos et al., 1998). It has previously been considered endemic to highlands in Costa Rica and Panama (Smith \& Schubert, 1958; BurtUtley, 1985). The above cited collection not only extends the range of this species north hundreds of kilometers but also represents a uncharacteristic elevation for this species. Burt-Utley (1985) reports that this species is found only within middle to high elevations (1050-3200 m), being most abundant at elevations above $1400 \mathrm{~m}$. She also reports the species is most abundant on the Pacific slopes in seasonally drier montane tropical forests. Our collection is from a mere $488 \mathrm{~m}$ in elevation and is in the Atlantic (Gulf of Mexico) drainage.

There is little doubt about the close relation between the plants collected at Poza Reina and Begonia involucrata as both share many characters including the unusual encircling outer inflorescence bracts and reduction of the inflorescence. The Mexican plants do show unique morphology compared to that described in the literature and compared to herbarium specimens from Costa Rica and Panama (Table 3). They may warrant recognition at the sub-specific level. Mexican plants have more glabrous leaf surfaces than plants from farther south where upper leaf surfaces are always scabrid-hirtellous. The leaf texture is much thinner on Mexican plants being membranaceous to chartaceous versus subcoriaceous to coriaceous in plants from Costa Rica and Panama. The stem is correspondingly much less pubescent, being merely moderately villous on young growth and glabrate in age. Petioles in Mexican plants are likewise not nearly as densely pubescent. Additionally, stamen coloration tends to be lighter in Mexican plants and the tepals are always a clear white. Though not reported in prior taxonomic treatments of B. involucrata, the intense honeylike fragrance of both staminate and pistillate flowers in this taxa is unique among those known from Veracruz. This trait is reported in pollination and natural selection studies (Agren \& Schemske, 1991; Schemske \& Agren, 1995). In large populations 
Table 3. Morphological characteristics of Begonia involucrata and related cane-forming species.

\begin{tabular}{|c|c|c|c|c|c|}
\hline Character & $\begin{array}{l}\text { Begonia involucrata Liebm., } \\
\text { Mexican Populations }\end{array}$ & $\begin{array}{l}\text { Begonia involucrata Liebm., } \\
\text { Central American Populations }\end{array}$ & $\begin{array}{l}\text { Begonia broussonetiifolia } \\
\text { A. DC. }\end{array}$ & Begonia corredorana C. DC. & Begonia multinervia Liebm. \\
\hline Leaf & $\begin{array}{l}\text { Membranaceous, unlobed } \\
\text { with two attenuate- } \\
\text { acuminate appendages, } \\
\text { glabrous above, pubescent on } \\
\text { nerves below, deeply cordate } \\
\text { with overlapping lobes }\end{array}$ & $\begin{array}{l}\text { Coriaceous to subcoriaceous, } \\
\text { hirtellous and scabrid above } \\
\text { and hirtellous beneath, } \\
\text { sinuately lobed, deeply or } \\
\text { shallowly cordate }\end{array}$ & $\begin{array}{l}\text { Chartaceous to coriaceous, } \\
\text { distally } 2-3 \text { lobed with lobes } \\
1 / 3 \text { to } 2 / 3 \text { the width of the leaf } \\
\text { blade, glabrous to hirtellous } \\
\text { above and tomentose on } \\
\text { nerves below }\end{array}$ & $\begin{array}{l}\text { Membranaceous to } \\
\text { chartaceous, sometimes } \\
\text { with attenuate-acuminate } \\
\text { projections, glandular-hirsute } \\
\text { above and below, leaves } \\
\text { broadly and shallowly cordate }\end{array}$ & $\begin{array}{l}\text { Chartaceous, unlobed with } \\
\text { two attenuate-acuminate } \\
\text { appendages, essentially } \\
\text { glabrous above, lower surface } \\
\text { maroon to green, glabrous } \\
\text { or sparsely pilose on nerves, } \\
\text { shallowly cordate }\end{array}$ \\
\hline Petiole & $\begin{array}{l}\text { Light green, } 10-30 \text { (50) } \\
\text { cm long, sparsely strigose } \\
\text { to setose with whiplash } \\
\text { trichomes, somewhat rufous- } \\
\text { colored trichomes above, } \\
\text { becoming glabrate below }\end{array}$ & $\begin{array}{l}\text { Light green, } 5-33 \mathrm{~cm} \text { long, } \\
\text { densely pilose to tomentose } \\
\text { with coarse whiplash } \\
\text { trichomes }\end{array}$ & $\begin{array}{l}\text { Deep red, } 6.8-16 \mathrm{~cm} \text { long, } \\
\text { densely tomentose }\end{array}$ & $\begin{array}{l}\text { Light green, sometimes } \\
\text { infused with red, } 7-10 \mathrm{~cm} \\
\text { long, moderately to densely } \\
\text { villous with spreading } \\
\text { rounded or flattened } \\
\text { trichomes }\end{array}$ & $\begin{array}{l}\text { Maroon to green, } 4-20 \mathrm{~cm} \\
\text { long, sparsely antrorsely } \\
\text { villous }\end{array}$ \\
\hline Peduncle & $\begin{array}{l}\text { Green to rufous, } 15-30 \mathrm{~cm} \\
\text { long, sparsely pubescent } \\
\text { below with setose trichomes, } \\
\text { becoming more densely } \\
\text { pubescent above with } \\
\text { numerous rufous-setose } \\
\text { trichomes }\end{array}$ & $\begin{array}{l}\text { Light green, } 14-47.5 \mathrm{~cm} \text {. long, } \\
\text { sparsely to densely pubescent } \\
\text { with setose trichomes } \\
\text { becoming more densely } \\
\text { pubescent above with rufous- } \\
\text { setose trichomes }\end{array}$ & $\begin{array}{l}\text { Green sometimes suffused } \\
\text { with pink, } 14.6-29 \mathrm{~cm} \text { long, } \\
\text { sparsely to densely tomentose }\end{array}$ & $\begin{array}{l}\text { 12.3-35.5 cm long, sparsely } \\
\text { glandular-pilose }\end{array}$ & $\begin{array}{l}\text { Green, } 7-39 \mathrm{~cm} \text { long, glabrous } \\
\text { to sparsely pilose }\end{array}$ \\
\hline Stamens & $\begin{array}{l}27-42, \text { filaments of equal } \\
\text { length or slightly longer than } \\
\text { anthers }\end{array}$ & $\begin{array}{l}\text { 16-62, filaments and anthers } \\
\text { of nearly equal length }\end{array}$ & $\begin{array}{l}21-34, \text { filaments shorter to } \\
\text { nearly as long as the anthers }\end{array}$ & $\begin{array}{l}16-41 \text {, filaments as long to } \\
\text { longer than the anther }\end{array}$ & $\begin{array}{l}\text { 16-35, filaments shorter to } \\
\text { much shorter than the anthers }\end{array}$ \\
\hline Capsules & $\begin{array}{l}\text { Pedicels } 25-34 \mathrm{~mm} \text { long, } \\
\text { capsule } 8-11 \mathrm{~mm} \text { long, } \\
\text { longest wing } 15-20 \text { X } 10-13 \\
\text { mm, obovate to elongate- } \\
\text { dolabriform, the apex } \\
\text { broadly obtuse or truncate, } \\
\text { often lobed }\end{array}$ & $\begin{array}{l}\text { Pedicels } 15-60 \mathrm{~mm} \text { long, } \\
\text { capsules 6-11 mm long, } \\
\text { longest wing } 8-23 \text { X 7-13 mm, } \\
\text { oblong, ovate, suborbicular or } \\
\text { narrowly dolabriform }\end{array}$ & $\begin{array}{l}\text { Pedicels } 11-21 \mathrm{~mm} \text { long, } \\
\text { capsules } 5-8 \mathrm{~mm} \text { long with } \\
\text { longest wing } 11-15 \times \mathrm{X}- \\
11 \mathrm{~mm} \text {, apically oblique, } \\
\text { truncate, obtuse to subacute }\end{array}$ & $\begin{array}{l}\text { Pedicels } 7-23 \mathrm{~mm} \text { long, } \\
\text { capsule } 5-9 \mathrm{~mm} \text { long, longest } \\
\text { wing } 12-22 \text { X } 7-11 \mathrm{~mm} \\
\text { narrowly ovate to oblong or } \\
\text { subdolabriform }\end{array}$ & $\begin{array}{l}\text { Pedicels 5-25 mm long, } \\
\text { capsule 6-14 mm long, longest } \\
\text { wing 8-18 X 6.5-11 mm, } \\
\text { ovate-triangular, obovate- } \\
\text { elliptic or dolabriform }\end{array}$ \\
\hline
\end{tabular}


the fragrance produced from these flowers may be evident at a distance of a hundred meters.

Epidermal peels from several plants in the population all displayed solitary stomata. This observation is and important one in that the section Gireoudia has been reported to show stomata predominantly in clusters of 2-5, occassionally mixed with single ones. Doorenbos et al. (1998) report that solitary stomata have only been confirmed in one species, B. hydrocotylifolia within this section. Given that Begonia involucrata is the type of the section and solitary stomatal arrangement has been seen in at least five additional species, stomatal clusters probably should not be considered diagnostic of sect. Gireoudia. Stomatal arrangement may not be as useful as once thought in determination of sections as we report at least two sections which show a mixture of stomatal arrangements in clusters and singly (see discussion under $B$. lyniceorum below). The presence of stomatal clusters in Begonia has been proposed as a water conservation strategy (Hoover, 1986). The perpetually moist habitat of B. involucrata at the Poza Reina site does not indicate that adaptations for water conservation would be necessary in this habitat. Some species from seasonally dry habitats such as $B$. peltata display solitary or less frequently paired stomata and would seem to question the theory that stomatal clusters are an example of a water preservation strategy.

The Mexican population of Begonia involucrata could be confused with several other suffrutescent species from section Gireoudia including Begonia corredorana, $B$. multinervia, and $B$. broussonetiifolia (Table 3 ). The only other species sharing the large, encircling, caducous inflorescence bract is Begonia brossounetiifolia. From this species it may be distinguished by the green rather than red culm that is not densely tomentose, the strongly cordate leaf base, longer capsule pedicels, 25-34 mm long vs. 11-21 mm long, strictly two tepals (B. broussonetiifolia may exhibit 4), and larger capsule wings 11-15 mm long vs. 8-10 mm long in B. broussonetiifolia. Begonia broussonetiifolia is documented solely from Costa Rica, though it has been reported from Nicaragua and Guatemala without specific location information (Burt-Utley, 1985). Begonia multinervia, which occurs from southern Nicaragua to central Panama, shares the character of glabrous upper leaf surfaces with the Mexican plants of $B$. involucrata but does not show the reduced inflorescence and involucral bracts. $B$. multinervia also typically displays maroon lower leaf surfaces and green to pink bracts.

The Sierra de los Tuxtlas ecoregion is a volcanic region located in the coastal plain of the Gulf of Mexico known for its high biodiversity and endemism that contains the northernmost limit of tropical rainforest to be found on the American continent (Dirzo and Miranda, 1991). This region combines species typical of tropical 
rainforests to the south with more boreal species such as Liquidambar styraciflua $\mathrm{L}$. Uncommon Begonia species such as B. sousae Burt-Utley and species more typical of areas farther to the south such as B. sericoneura and B. involucrata are located in this area. The region is classified as a hot climate without frost and the collection site for B. involucrata is located in a region known to experience 3000-4000 $\mathrm{mm}$ of rainfall per year (García, 1970). This rainfall is more evenly distributed throughout the year than in many other forested areas of Veracruz but is most frequent in the summer months (García, 1970). The result of ample rainfall, warm climate, and rich volcanic soil is the development of a lush broad-leaved evergreen forest (selva alta perennifolia) in areas below $700 \mathrm{~m}$ in elevation (Gómez-Pompa, 1973). B. involucrata is found rooted in shallow to deep soil in moist to wet areas over volcanic rock. It forms large colonies in undisturbed to moderately disturbed lowland broad-leaved evergreen tropical forests on stream banks and near a cascade. Despite the fact that $B$. involucrata regularly grows on moist road banks and disturbed areas in Costa Rica and Panama no other populations could be located in the adjacent areas in this habitat. The Sierra de los Tuxtlas region has been and continues to be subjected to accelerated rates of deforestation with approximately $84 \%$ of the original forest cover removed as of 1986 and deforestation rates of 4.2-4.3\% annually (Dirzo and García, 1992). Begonia involucrata should be considered critically imperiled in Mexico.

Begonia lyniceorum K. Burt-Utley (fig. 2)

Newly reported collections: MEXICO: Veracruz. Mun. Jesús Carranza. Epipetric on limestone of dark, shaded ledges of cave entrance, $6.5 \mathrm{~km}$ north of the road from La Laguna to Helio García Alfaro, south of Nuevo Acapulco and Belisario Domínguez, 22 October 2004, Rekha Morris, RM-04-167 (CLEMS, XAL), specimen identified by P. D. McMillan.

Description: Plants forming colonies by thin, 2-7 $\mathrm{mm}$ thick glabrous (smooth), creeping rhizomes with internodes 9-14 mm long. Leaves 5-12 cm long and 3-9 cm wide, very thick and succulent when fresh, ovate with abruptly acuminate tips with distinctively peltate leaf attachments, margins crenate-dentate, though often obscurely so. Stomata occurring singly or in clusters of 2 or 3 . The upper and lower leaf surfaces and petioles are glabrous with the upper surface darker green and the lower surface paler, veins obscured in fresh material above, apparent upon drying. Staminate flowers are small, with 2 oblong sepals $4.5-5.0 \mathrm{~mm}$ long and 3.0-3.5 mm wide and 2 much thinner (less than $1 \mathrm{~mm}$ wide) petals to $3 \mathrm{~mm}$ in length; stamens 11-20. Sepals white distally, becoming pink towards the base. Pistillate flowers with 


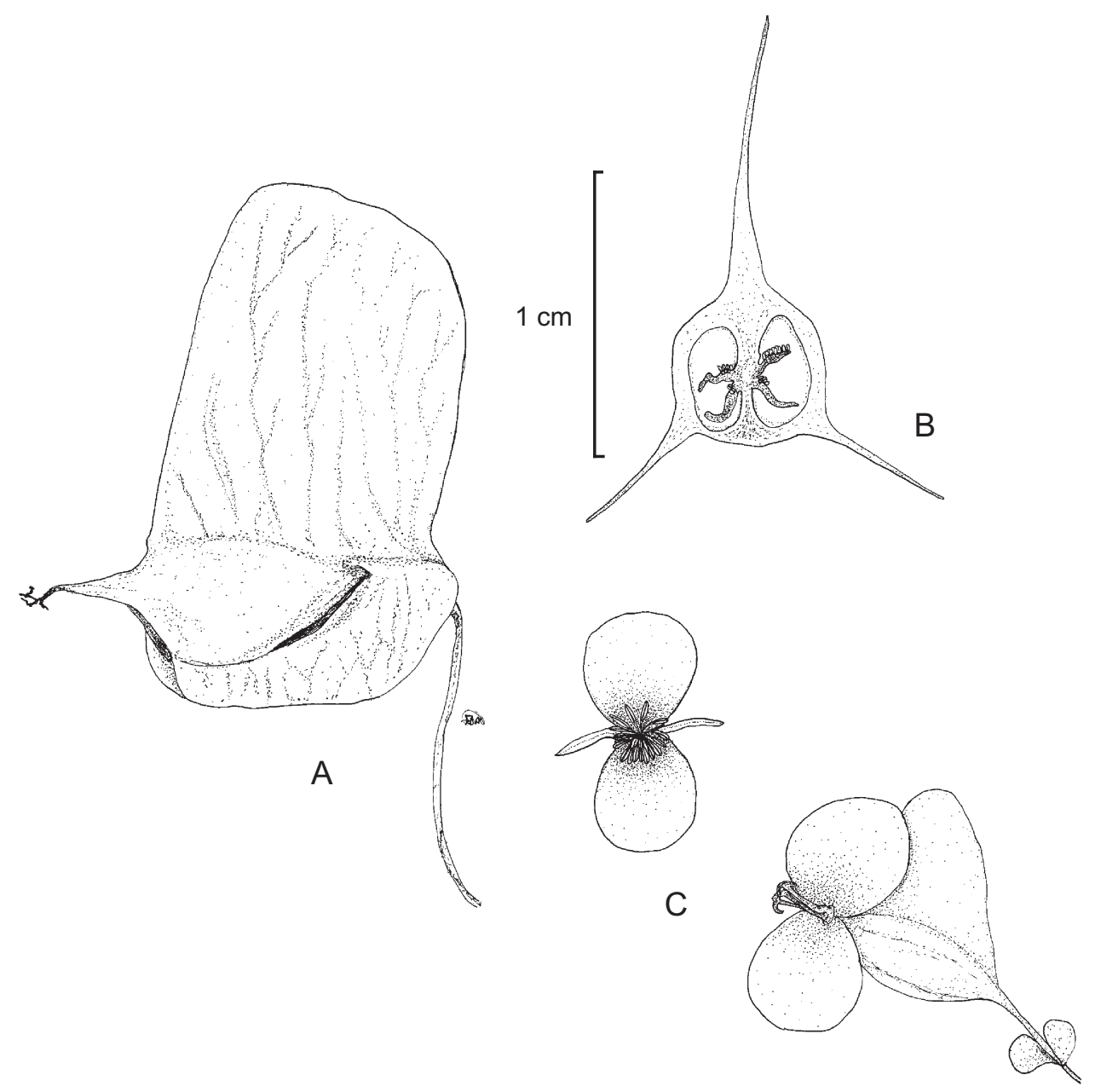

Fig 2. Begonia lyniceorum K. Burt-Utley. A. Mature capsule; B. Cross section of mature capsule (bilocular) showing bilamellate placentation; C. Male and female flower detail.

2 sepals, suborbicular, $4 \mathrm{~mm}$ long and 4.0-5.0 $\mathrm{mm}$ wide, coloration as in staminate flowers; ovary bilocular, placentation bilamellate-axillary; styles 3 , to $3 \mathrm{~mm}$ long, fused for less than $1 / 3$ of their length, stigmas bicornute. Capsules on pedicels 8$13 \mathrm{~mm}$ long, slightly nutant, thick and with a cartilaginous texture when mature, light brown to straw-colored when ripe, 9-15 mm long with 3 unequal wings, the upper wing longest, broadly triangular to dolabriform with an obtuse tip, 9-13 $\mathrm{mm}$ long and 8-11 $\mathrm{mm}$ wide at base, much longer than the 2 lower wings which 
are asymmetrically lunate, $3-4 \mathrm{~mm}$ long and $9-10 \mathrm{~mm}$ wide at the base. Capsules dehiscent via longitudinal slits at the base of the two lower, smaller wings. Flowering and fruiting from June through October.

This highly localized, endemic Begonia has been collected from a very limited area in the Isthmus of Tehuantepec in lowlands with limestone-karst geology. The description by Burt-Utley (1983) was based upon 5 sheets all collected at the same location, from the same population on the same date. The above amplified description is based both on the original collection and on the newly collected material cited above. Major revisions to the original description include leaf texture, which is decidedly succulent and thick coriaceous when fresh, drying to subcoriaceous or chartaceous, more precise floral descriptions and the first description of the capsule and increased ranges for several vegetative features such as rhizome width and leaf dimensions.

This species was placed in section Weilbachia by Burt-Utley (1983) without examination of mature capsules to confirm locule partitioning. The report of stomatal clusters in this species represents the first documentation of stomatal clusters in section Weilbachia (Doorenbos et al., 1998). The bilocular ovaries are the primary morphological feature utilized to recognize section Weilbachia and with additional molecular examination this section may be found to be polyphyletic and in need of revision. As noted by Burt-Utley (1983), this species is probably most closely related to Begonia calderonii Standl., which is also epipetric with very similar growth habit and rhizomes. With the new collections of mature, fertile capsules, the distinctions with that species can now be quantified beyond the simple lack of pubescence in B. lyniceorum that is noted by Burt-Utley (1983). The capsules of $B$. calderonii are two-locular but display a single, very elongate $(15-20 \mathrm{~mm})$, falcate, obtuse wing and does not display the two smaller lunate wings seen in Begonia lyniceorum (Smith and Schubert, 1961). Additionally, the ovary in B. calderonii is reported to be hirsute in contrast to the glabrous ovary of B. lyniceorum. The peltate leaves of $B$. lyniceorum may cause confusion with some members of section Gireoudia, resembling Begonia conchifolia A. Dietr. or B. peltata. From these species it may be immediately separated by the glabrous foliage and petioles and more narrow, creeping rhizome.

Habitat is not addressed in the original description of B. lyniceorum, though it is detailed on the type specimen collection label. The habitat of the type collection was reported as growing (epipetric) on limestone walls of large karst-sink and springhead in selva mediana. At our location the plants are also epipetric growing directly on the limestone or on very shallow soil pockets at the entrance to a cave 
within low semi-evergreen tropical forest. The plants were growing in a highly shaded environment in association with $B$. imperialis at low elevations (less than $150 \mathrm{~m}$ ). Other Begonia species found in the general region include $B$. heracleifolia, B. nelumbiifolia, and their hybrid. This species is critically endangered in the wild and may be the rarest of the Mexican species, very little available forested habitat remains in this area of Veracruz despite the remoteness of the region. This species may yet be found in the more extensive forests still existing in the Sierra de Tres Picos or elsewhere in the vast "Región de Los Chimalapas."

\section{Begonia sericoneura Liebm.}

Newly reported collections: MEXICO: Veracruz. Mun. Zongolica. Growing in low-montane semi-evergreen forest approximately, $500 \mathrm{~m}$. elevation, near Zongolica, 30 December 2002, Rekha Morris, RM-02-50 (CLEMS, XAL); Mun. San Andrés Tuxtla, growing along roadside through selva alta perennifolia, Nanciyaga, 9 March 2004, Rekha Morris, RM-04-127 (CLEMS); Mun. San Andrés Tuxtla. Growing epipetric on boulder of volcanic rock in association with Begonia pinetorum and B. heracleifolia, road to Poza Reina, 21 October 2004, Rekha Morris, RM-04-152 (CLEMS).

The above collections represent the first report of this wide-ranging species for the state of Veracruz. It has previously been reported from northern Oaxaca, the Isthmus of Tehuantepec in Oaxaca, Quintana Roo, and from Chiapas (Burt-Utley, 1985). The species ranges from Oaxaca south through Central America to Colombia, mostly in low elevation broad-leaved tropical forests. In Veracruz, the species is encountered in shallow soil on limestone or volcanic rock or on road banks through semi-evergreen and evergreen broad-leaved tropical forest at elevations mostly below $500 \mathrm{~m}$.

\section{Begonia sousae K. Burt-Utley}

Newly reported collections: MEXICO: Veracruz. Mun. Growing on roadbank along road between Tlapacoyan and Altotonga, 12 October 2003, Rekha Morris, RM-03-110 (CLEMS); small population around waterfall near forest farmer's pasture on side road out of Coyame leading into the Sierra de Santa Marta, south of Laguna Catemaco, sympatric with B. theimei, 15 February 1982, W. S. Hoover 397 (CLEMS, GH); Mun. San Andrés Tuxtla, selva alta perennifolia adjacent to stream and cascades near Poza Reina, east of Lake Catemaco, 9 March 2004, Rekha Morris, RM-04-128 (CLEMS), specimen identified by P.D. McMillan; same location, 18 March 2004, P. D. McMillan 7312 with Rekha and Michael Morris (CLEMS). 
The original description of this species was based upon three sheets from two populations and is representative of only a portion of the variation exhibited by this species. Jiménez and Schubert (1997) report additional five collections all from the Sierra de Los Tuxtlas area. We report three additional locations for Veracruz including one population from an area far removed from Los Tuxtlas. From examination of living and herbarium specimens, it is apparent that several aspects of the description are in need of revision. The leaves of this species are reported as sparingly hirtellous beneath on principal nerves (Burt-Utley, 1983), but the characters of leaf and petiole pubescence are more variable than is suggested by this statement. Many plants produce extremely densely hirtellous pubescence with rufous-colored trichomes throughout the leaf surface when young and become less copiously hirtellous with age. The petioles are similarly more densely hirtellous when young, and are typically moderately rather than sparsely hirtellous in most specimens upon maturity. The upper leaf surface in juvenile specimens displays distinctive deep purple or brownish blotches in the axils of the veins above, similar to those seen in B. squarrosa Lieb. and B. stigmosa Lindl. Stomata are produced in clusters of mostly 2-3 intermixed with single stomata. The outer surface of the light pink staminate and pistillate sepals as well as the capsule are evidently and distinctly punctate-spotted with darker pink in fresh material.

The thin villi typical of this species are uncommon within section Gireoudia in Veracruz, occurring also in B. sericoneura and B. carolineifolia. This character coupled with the few stamens (6-9, very rarely ranging to 12) make this species readily identified among the species in Veracruz with apically acuminate leaves. The submarginal short-villi on the upper leaf surface reported by Burt-Utley (1983) have been noted to be inconspicuous in most specimens and nearly absent on larger, more mature leaves. Begonia sousae shares many characteristics in common with and likely belongs with the $B$. stigmosa species group, including the small number of stamens, small sepals and capsules, asymmetrically oblong-elliptic to ovate leaf shape, and large purplish blotches in the axils of young leaves.

In addition to the few records collected from the region of Sierra de Los Tuxtlas and a specimen collected from near Tlapacoyan by R. Morris, this species has been collected in the state of Oaxaca at least twice. In 1983 it was collected from near Acatlán, Oaxaca by Mr. Whitlock. Specimens of this plant, recognized as an undescribed species by Mr. Whitlock were taken to the Los Angeles County Arboretum, Los Angeles, California, U.S.A., and grown in cultivation there. A photograph of Mr. Whitlock's specimens were identified later by K. Burt-Utley as $B$. sousae, though they were not mentioned in her description of the species (Burt- 
Utley, 1983) nor in Jiménez and Schubert (1997). An additional Oaxacan specimen collected along a roadbank just east of La Esperanza on 26 February 1982 ( $W$. S. Hoover 417, CLEMS, GH) has also been determined by P.D. McMillan to be representative of Begonia sousae.

This species has been located growing in shallow soil over volcanic rock or limestone in tall, broadleaved tropical forests (selva alta perennifolia) as well as in semi-evergreen and second growth forests (selva mediana subcaducifolia). This species is most commonly found along rivers or in areas with some influx of light such as along paths or road banks through intact forest. Like most other Begonia species, this one is found only in association with calcareous or mafic rock.

\section{ARTIFICIAL KEY TO THE SPECIES OF BEGONIA OF VERACRUZ}

$1 \quad$ Plants with palmately compound leaves 2

1 Plants with simple, lobed or unlobed leaves, sometimes deeply lobed but never compound .................................................................................. 3

2 (1) Flowers greenish; leaves thin, membranaceous, paper-thin when dry and often disintegrating on herbarium specimens, glabrous above and below or with sparse pubescence along the veins below; rhizomes repent

Begonia thiemei

2 Flowers pink to white; leaves thicker, subcoriaceous when fresh, drying without excessive damage, glabrous above, veins and petioles with long rusty trichomes below when young, glabrate with age; rhizomes ascending, extremely large and thick (mostly more than $5 \mathrm{~cm}$ thick)

Begonia carolineifolia

3 (1) Leaf attachment peltate on adult leaves ..................................................... 4

$3 \quad$ Leaf attachment not peltate …………………………………………....... 7

4 (3) Leaf surfaces essentially glabrous to sparsely hirsute on the veins beneath; rhizomes erect to ascending ………......................................... 5

4 Leaf surfaces densely pubescent when young, sometimes becoming glabrate with age; rhizomes erect to ascending ................................... 6

5 (4) Capsules 3-locular; plants robust, more than $30 \mathrm{~cm}$ tall, often over $1.0 \mathrm{~m}$ tall; veins evident on upper leaf surface, leaves not succulent, adult leaves more than $20 \mathrm{~cm}$ long; rhizome more than $10 \mathrm{~mm}$ thick Begonia nelumbiifolia 
5 Capsules 2-locular; plant diminutive, less than $30 \mathrm{~cm}$ tall; veins obscure on upper leaf surface, leaves thick and succulent when fresh, chartaceous upon drying, adult leaves less than $12 \mathrm{~cm}$ long, rhizome long and creeping, $7 \mathrm{~mm}$ or less thick, repent .......................... Begonia lyniceorum

6 (4) Staminate flowers with 4 tepals (2 sepals, 2 petals); capsules with 3 subequal wings; leaves without a cordate base, densely lanose when young, margin sinuate-dentate to entire

Begonia peltata

6. Staminate flowers with 2 tepals (sepals); capsules with 3 unequal-sized wings the longest up to 2 times longer than the two smaller wings; leaves with a cordate base, moderately lanose, margins prominently dentate to doubly serrate on the margin

Begonia polygonata

7 (3) Plants erect with elongate, succulent stems or elongate suffrutescent

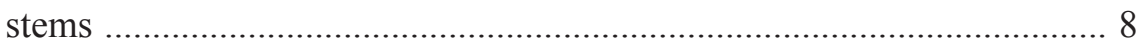

$7 \quad$ Plants with decumbent, prostrate, creeping, or short erect rhizomes ....... 15

8 (7) Plants with elongate suffruticose (semi-woody) aerial stems, long-lived perennials ("cane species") .................................................................... 9

8 Plants without suffruticose aerial stems, instead being fibrous-rooted and short-lived or tuberous with elongate, herbaceous stems ......................... 10

9 (8) Stamens 11-19; pistillate pedicels 6-18 $\mathrm{mm}$ long; leaf blades reniform to oblong, marginally broadly lobed with primary lobe opposite the petiole insertion ….......................... Begonia sartorii

9 Stamens 27-42; pistillate pedicels 25-34 mm long; leaf blades broadly ovate with 1-2 acuminate-cuspidate lobes/tips ..... Begonia involucrata

10 (8) Capsules dehiscent via lunate slits at the base of the capsule; stems, petioles and leaves with a dense mixture of coarse and fine pubescence

Begonia wallichiana

10 Capsules, not dehiscent via lunate slits at the base of the capsule; stems, petioles and leaves variously pubescent or glabrous but not with a dense mixture of coarse and fine pubescence

11 (10) Leaves irregularly 3-5 lobed, obliquely acuminate, sparsely pilose ......... Begonia falciloba

11 Leaves variously ovate to elliptic but without conspicuous irregular lobes, variously pubescent

12 (11) Leaves ovate, with crenulate margins, only slightly oblique to nearly symmetric with apex obtuse Begonia fischeri

12 Leaves ovate to elliptic with serrate or serrate dentate margins (not crenulate), oblique, with apex acuminate 
13 (12) Plants with bulbils produced in leaf axils; floral bracts persistent Begonia gracilis

13 Plants without bulbils in the leaf axils; floral bracts caducuous 14

14 (13) Capsules 2-locular, with 3 short wings of nearly equal length; plants suberect to reclining repent Begonia oaxacana

14 Capsules 3-locular, with 3 unequal wings, the upper wing consicuously longer; plants erect, sometimes tipping over with age ..... Begonia incarnata

15 (7) Rhizomes less than $1 \mathrm{~cm}$ thick, succulent and creeping with relatively elongate internodes; capsules 2 or 3-locular ..... 16

15 Rhizomes more than $1 \mathrm{~cm}$ thick, horizontal and prostrate, decumbent, ascending or erect; caspsules 3-locular .................................................... 19

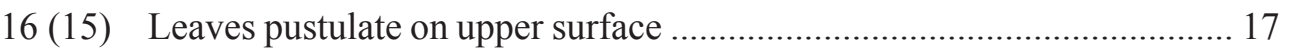

$16 \quad$ Leaves not pustulate on upper surface ................................................. 18

17 (16) Staminate flowers with 4 tepals (2 sepals, 2 petals) pistillate flowers with 3 tepals ( 2 sepals, 1 petal); leaves predominantly unmottled or rarely mottled with white, ovate to broadly ovate, obliquely asymmetrical at the base, with short acuminate tip Begonia pustulata

17 Staminate and pistillate flowers with 2 tepals (sepals); leaves deep, dark green above with a broad area of lighter green or whitish variegation along the midrib, dark and often purplish below, ovate, slightly asymmetrical to nearly symmetrical at base, with elongate acuminate tip ......... Begonia imperialis

18 (16) Capsules 3-locular; female flowers with 5 tepals ( 2 sepals, 3 petals); leaves without lobes, bases rounded, nearly symmetrical ........ Begonia glabra

18 Capsules 2-locular; female flowers with 2 tepals (sepals), petals lacking; leaves (at least some plants in the population) with one or more narrow, marginal lobes with long acuminate tip, leaf with asymmetrical to nearly symmetrical cordate to rounded bases Begonia ludicra

19 (15) Rhizomes erect or ascending, sometimes reclining with age ................ 20

19 Rhizomes creeping, prostrate or decumbent, not evidently erect or

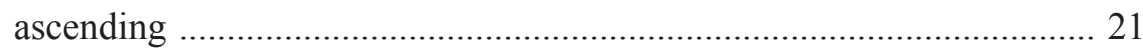

20 (19) Rhizomes erect with persistent stipules; petioles villous with fine rufous to blonde hairs when young, glabrate in age; leaves broadly ovate to suborbicular with deep cordate base, often with basal lobes overlapping, reddish spot often present at petiole junction on upper surface of leaf; evenly hirsute to pilose above, especially on primary veins, glabrate below or with long rufous to blonde villous trichomes at vein intersections Begonia sericoneura 
20 Rhizomes ascending, stipules not persistent; petioles not villous; leaves ovate, glabrous above, undersurface with conspicuous tufts of lacerate scales along the major veins and dense concentric rings of squamose trichomes on the upper petiole just below the blade junction

Begonia manicata

21 (19) Leaves deeply palmately lobed as adults; petiole densely covered with laciniate, villous or squamose trichomes, especially when young, petiole tufted with one or two concentric rings of flattened laciniate trichomes at the petiole-leaf blade junction Begonia heracleifolia

21 Leaves shallowly lobed or unlobed as adults; petiole without concentric rings of flattened laciniate trichomes at the petiole-leaf blade junction 22

22 (21) Capsules with 3 almost equal-sized wings; plants epipetric or in shallow soil over limestone, small, with thick, subcoriaceous leaves, tomentose above and beneath, though sometimes becoming glabrate above; petioles densely to moderately tomentose ........ Begonia pinetorum

22 Capsules with 3 unequal-sized wings, plants of various habitats and size with membranaceous to chartaceous leaves, variously pubescent ........... 23

23 (22) Largest leaves no more than $7 \mathrm{~cm}$ long, obliquely orbicular to transversely elliptic, glabrous above with ciliate margins; inflorescence symmetrical Begonia hydrocotylifolia

23 Largest leaves much longer than $7 \mathrm{~cm}$ long, of various shapes and either glabrous or variously pubescent; inflorescence asymmetrical (except in $B$. barkeri) 24

24 (23) Stamens 6-9; leaves glabrous above with a submarginal band of short villi; petioles densely hirtellous with rufous-colored trichomes becoming sparser with age; outer surface of sepals and capsules punctuate dotted ("polkadot") with deep red against the pink colored sepals and capsules when fresh

Begonia sousae

24 Stamens more than 9; leaves glabrous or pubescent above without a submarginal band of short villi; petioles not hirtellous; outer surface of sepals and capsules not consicuously punctuate dotted

25 (24) Petioles covered with large, wide laciniate trichomes; leaves large (to $60 \mathrm{~cm}$ or more long), ovate, asymmetric and glabrous above with ciliate margins; inflorescence symmetrical; stamens 11 or less ......... Begonia barkeri

25 Petioles not covered with large, wide laciniate trichomes; leaves various; inflorescence asymmetrical; stamens more than 11 26 
26 (25) Stamens more than 50 per staminate flower; plants with large to giant sized leaves (often more than $50 \mathrm{~cm}$ wide and long) ..................................... 27

26 Stamens less than 50 per staminate flower; plants with medium sized leaves (less than $50 \mathrm{~cm}$ wide and long) ............................................... 28

27 (26) Largest wing of capsule shallow, 8-12 mm wide with eciliate margins; stamens 78-98; leaf blades with 12-14 nerves, sparingly puberulous ..... Begonia multistaminea

27 Largest wing of capsule elongate, $15-38 \mathrm{~mm}$ wide with ciliate margins; stamens 50-82; leaf blades with 10-12 nerves, sparsely hirsute

Begonia fusca

28 (26) Staminate flowers with 4 tepals (2 petals, 2 sepals); stamens $28-32$..... Begonia pudica

28 Staminate flowers with 2 tepals (sepals); stamens 15-32 ….................. 29

29 (28) Stamens 15; peduncles glabrescent; leaves 7-9 palmatinerved; often drought deciduous Begonia plebeja

29 Stamens 19-32; peduncles pubescent, leaves 10-12 palmatinerved; not drought deciduous Begonia karwinskyana

\section{ACKNOWLEDGMENTS}

The authors are indebted to the assistance and valuable information provided by Jack Golding, and the curatorial staff of the following institutions, DUKE, F, GH, MEXU, NY, XAL for access to the collections. We are especially grateful to Dr. Victoria Sosa and Gonzalo Castillo Campos, Dr. Francisco G. Lorea for facilitating Morris' research. Three of the six exploratory trips (Dec. 2002 to Jan 2003, October 2003 and March 2004) to Mexico to document the Begonia of Veracruz by Morris were funded by grants from the American Begonia Society, contributions from its chapters (Astro Branch, Alamo Branch, Fred A. Barkley Branch, Bessie Buxton Branch, Greater Atlanta Branch, Greater Chicago Branch, Houston Satellites Branch, Palm Beaches Branch, Sacramento Branch, San Francisco Branch, San Jacinto Branch, Theodosia Burr Shepherd Branch, Westchester Branch), and individual members (Tom Keepin, Morris Mueller, Janet Brown, Carol Notaras, Howard Berg, Thelma O’Reilly, Freda Holley, Daniel Haseltine, Frank Green, John Harrington, Gene and Ann Salisbury, Normand Dufresne, Dale Sena, Jackie Davis, and Ruth Wilson). We would also like to acknowledge the assistance and hospitality provided by Michael Marino and Bruce Pearson of Tropical World de Las Flores near Fortín during our visits to Veracruz state. 


\section{LITERATURE CITED}

Agren, J. and D.W. Schemske. 1991. Pollination by deceit in a neotropical monoecious herb, Begonia involucrata. Biotropica 23: 235-241.

Burt-Utley, K. 1983. Three new species of Begonia (Begoniaceae) from Mexico. Brittonia 35: $115-119$.

Burt-Utley, K. 1985. A revision of Central American species of Begonia section Gireoudia (Begoniaceae). Tulane Studies in Zoology and Botany 25: 3-123.

Dirzo, R. and A. Miranda. 1991. El límite boreal de la selva tropical húmeda en el continente americano: contracción de la vegetación y solución de una controversia. Interciencia 16: 240-247.

Dirzo, R. and M. C. García. 1992. Rates of deforestation in Los Tuxtlas, a neotropical area in southeast Mexico. Conserv. Biol. 6: 84-90.

Doorenbos, J., M. S. M. Sosef and J. J. F. E. de Wilde. 1998. The sections of Begonia, studies in Begoniaceae IV. Wageningen Agricultural University Papers 98-2. Wageningen, Netherlands. 266 pp.

García, E. 1970. Los climas del estado de Veracruz. Anales Inst. Biol. Univ. Nac. Autón. México, Ser. Bot. 41: 3-42.

Golding, J. and D. C. Wasshausen. 2002. Begoniaceae; 2nd ed. Dept. of Systematic BiologyBotany, National Museum of Natural History. Washington, D.C. 289 pp.

Gómez-Pompa, A. 1973. Ecology of the vegetation of Veracruz, In: A. Graham (ed.). The vegetation and vegetational history of northern Latin America. Elsevier Scientific Publishing Co. Nueva York. pp. 73-148

Hoover, W. S. 1986. Stomata and stomatal clusters in Begonia: ecological response in two Mexican species. Biotropica 18: 16-21.

Jiménez, R. and B. G. Schubert. 1997. Begoniaceae. Flora de Veracruz 100: 1-72.

Schemske, D. W. and J. Agren. 1995. Deceit pollination and selection on female flower size in Begonia involucrata: an experimental approach. Evolution 49: 207-214.

Smith, L. B. and B. G. Schubert. 1958. Begoniaceae. Flora of Panama. Ann. Missouri Bot. Gard. 45: 41-67.

Smith, L. B. and B. G. Schubert. 1961. Begoniaceae. Flora of Guatemala. Fieldiana Bot. 24(7): 157-185.

Smith, L. B., D. C. Wasshausen, J. Golding and C. E. Karegeannes. 1986. Begoniaceae. Smithsonian Contributions to Botany 60: 1-584. 